Contacts

Publisher: Fabien Savenay

Editor: Paul Smaglik

Sales Director: Ben Crowe

European Head Office

London

The Macmillan Building

4 Crinan Street

London N1 9XW, UK

Tel +44 (0) 2078434961

Fax +44 (0) 2078434996

e-mail: naturejobs@nature.com

European Manager:

Nevin Bayoumi (4978)

UK/ RoW/ Ireland:

Matt Powell (4953)

Andy Douglas (4975)

Laura Pearson (4977)

Netherlands/ Italy/ Iberia:

Evelina Rubio Hakansson (4973)

Scandinavia: Sille Opstrup (4994)

Production Manager: Billie Franklin

To send materials use London

address above.

Tel +44 (0) 2078434814

Fax +44 (0) 2078434996

e-mail: naturejobs@nature.com

International

Advertising Coordinator

Hind Berrada (4935)

Naturejobs web development:

Tom Hancock

Naturejobs online production:

Ben Lund

European Satellite Offices

France/ Belgium:

Christine Niox-Chateau

Tel +33 (0) 143201651

Fax +33 (0) 143205152

e-mail.c nioxchateau@nature.com

Germany/ Austria/ Switzerland:

Patrick Phelan/ Kate Tumer

$\mathrm{Tel}+498954905711 /-2$

$\mathrm{Fax}+498954905720$

e-mails: p.phelan@nature.com

k.umer@nature.com

US Head Office, New York

345 Park Avenue South

10th Floor, New York, NY 10010-1707

Tel +1 8009897718

Fax +18009897103

e-mail: naturejobs@natureny.com

US Sales Director: Ben Crowe

US Sales Manager: Peyton Mason

US Advertising Coordinator:

Ashly de Leon

Japan Head Office, Tokyo

MG Ichigaya Building (5F),

19-1 Haraikatamachi,

Shinjuku-ku,

Tokyo 162-0841

Tel +81332678751

Fax +81332678746

e-mail:k.cowan@naturejpn.com

Japan Manager: Kate Cowan

\title{
naturejobs
}

\section{Talent tug-of-war}

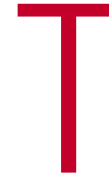

he past few years have seen the United States increase its reliance on scientists and engineers from abroad, while at the same time, these workers' home countries have made a more determined effort to reclaim lost talent. This set of events could mean trouble for the United States, says the National Science Foundation's Science and Engineering Indicators 2002 report, released this month (www.nsf.gov/sbe/srs/seind02).

According to the report, the percentage of foreign-born scientists and engineers in the United States is growing across all disciplines and at all degree levels. The proportions are at their highest for engineering (45\%), computer sciences (43\%) and mathematics $(30 \%)$, all of which are fields that are currently showing little or no growth in the production of domestic $\mathrm{PhDs}$.

If the ageing - and in some cases declining — pools of welltrained scientists in many industrialized nations are added to the equation, it is clear that there will be increased opportunities for young scientists outside the United States. A fact compounded by the efforts being made by many nations to build up their science and technology infrastructure and so recruit back their lost talent - a recurring theme in Naturejobs' Regions reports (see Naturejobs 4-5; 14 February 2002 and 4-5; 21 March 2002).

If this trend continues, the relative attractiveness of the United States as a destination for foreign-born scientists will decrease. "Although such a decline would be difficult to quantify," says the new report, "anecdotes suggest that experienced scientists and engineers, particularly those originally from Asia, are even now returning to their native countries."

So what does that mean for working scientists? More opportunities - especially if they work in maths, physics or chemistry and are willing to be flexible about where they live.

\section{Paul Smaglik}

Naturejobs editor
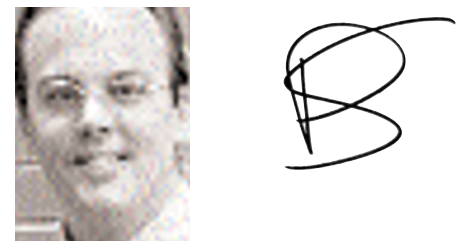

\section{Contents}

\section{POSTDOCS \& STUDENTS}

Easing the transition into postdoctoral research

\section{MOVERS}

Wellcome Trust chief retires; bioinformatics pioneer heads for pastures new; French research agency appoints lifesciences head; and more Back

WWW.NATUREJOBS.COM

Career centre

Information on the scientific job market

FOCUS

SPOTLIGHT

RECRUITMENT

SCIENTIFIC ANNOUNCEMENTS 